\title{
Regulation of carbon utilization by sulfur availability in Escherichia coli and Salmonella typhimurium
}

\author{
John A. Quan, ${ }^{1}$ Barbara L. Schneider, ${ }^{1}$ Ian T. Paulsen, ${ }^{1} \dagger$ \\ Mamoru Yamada, ${ }^{2}$ Nicholas M. Kredich ${ }^{3}$ and Milton H. Saier, Jr ${ }^{1}$
}

Author for correspondence: Milton H. Saier, Jr. Tel: +1 858534 4084. Fax: +1 8585347108.

e-mail:msaier@ucsd.edu

1 Department of Biology, University of California at San Diego, La Jolla, CA 92093-0116, USA

2 Department of Biochemistry, Yamaguchi University School of Medicine, Ube, Yamaguchi, Japan 755

3 Departments of Medicine and Biochemistry, Duke University Medical Center, Durham, NC 27710, USA

\begin{abstract}
Different pleiotropic transcriptional regulators are known to function in the coordination of regulons concerned with carbon, nitrogen, sulfur, phosphorus and iron metabolism, but how expression profiles of these different regulons are coordinated with each other is not known. The basis for the effects of cysB mutations on carbon utilization in Escherichia coli and Salmonella typhimurium was examined. cysB mutations affected the utilization of some carbon sources more than others and these effects could be partially, but not completely, reversed by the inclusion of cysteine or djenkolate in the growth medium. Assays of transport systems and enzymes concerned with glucitol and alanine utilization showed that these activities were depressed in cysB mutants relative to isogenic wild-type strains, and cysteine or djenkolate present in the growth media partially restored these activities. Using transcriptional fusions to the fdo (formate dehydrogenase) and gut (glucitol) operons, it was shown that decreased expression resulted from defects at the transcriptional level. Furthermore, the effects of loss of CysB were much less pronounced under conditions of catabolite repression than in the absence of a cataboliterepressing carbon source, and CAMP largely reversed the effect of the loss of CysB. Comparable effects were seen for $E$. coli lacZ gene expression under the control of its own native promoter, and sulfur limitation in a cysB mutant depressed net CAMP production in a cAMP phosphodiesterase mutant. Adenylate cyclase thus appears to be responsive to sulfur deprivation. These observations may have physiological significance allowing carbon and sulfur regulon coordination during the growth of enteric bacteria in response to nutrient availability.
\end{abstract}

Keywords: regulon, transcription, pleiotropic regulators, adenylate cyclase, CysB

\section{INTRODUCTION}

Bacteria require an ample supply of a variety of nutrients to maintain continuous growth. Among these nutrients are sources of carbon, nitrogen, phosphorus, sulfur and iron. The use of each such nutrient is in general controlled by one or a few pleiotropic transcriptional regulatory proteins. Thus, in Escherichia coli and the closely related Salmonella typhimurium, carbon utilization is regulated by the cAMP-receptor protein (CRP)

\footnotetext{
†Present address: The Institute for Genomic Research, 9712 Medical Center Drive, Manassas, VA 20850, USA.

Abbreviations: CRP, CAMP-receptor protein; EMB, eosin-methylene blue.
}

and the catabolite repressor/activator (Cra) protein (Saier \& Ramseier, 1996; Saier et al., 1996), nitrogen utilization is controlled by the NtrBC sensor kinase/ response regulator pair in conjunction with the $G \ln B$ and GlnD proteins (Magasanik, 1996; Reitzer, 1996a, b), phosphorus utilization is controlled by the PhoR/ PhoB sensor kinase/response regulator pair (Wanner, 1996), iron utilization is regulated by the Fur transcription factor (Earhart, 1996; Gralla \& Collado-Vides, 1996) and sulfur metabolism is controlled by the CysB transcriptional activator (Kredich, 1992).

The cysteine regulon includes most of the genes required for synthesis of cysteine and genes for uptake of sulfur sources such as L-cystine, sulfate, thiosulfate and taur- 
ine. Transcriptional activation of these genes requires CysB, the inducer $\mathrm{N}$-acetyl-L-serine and conditions of sulfur limitation (Kredich, 1992, 1996). CysB is a tetrameric LysR-type regulator with an N-terminal DNA-binding domain, a central inducer-binding domain and a C-terminal oligomerization domain that is essential for stability (Lochowska et al., 2001). Its activity is regulated by an efflux pump specific for cysteine metabolites (Dassler et al., 2000). CysB is also an autorepressor, preventing expression of its own structural gene, $c y s B$.

E. coli and S. typhimurium can utilize a number of sulfur-containing compounds as sole sulfur source, including sulfate, sulfite, thiosulfate, sulfide, glutathionine, lanthionine, taurine and L-djenkolate $\left[S, S^{\prime}\right.$ methylene bis(cysteine)] as well as cysteine and cystine (Kredich, 1996; van der Ploeg et al., 1997). Although these organisms cannot utilize methionine as a sole sulfur source, Klebsiella strains can (Seiflein \& Lawrence, 2001). Sulfide and thiosulfate are antiinducers, probably exerting their effects by competing with $\mathrm{N}$-acetyl-L-serine for binding to the CysB activator (Hryniewicz \& Kredich, 1991; Ostrowski \& Kredich, 1990). Cysteine inhibits inducer synthesis, resulting in maximal repression of the sulfur regulon. Growth with poor sulfur sources such as L-djenkolate or glutathione results in maximal derepression of the sulfur regulon. Rapid growth on rich media results in moderate induction of the regulon (Antón, 2000).

Hartmann \& Boos (1993) demonstrated that mutations in $p h o B$, the gene encoding the pleiotropic activator of the pho regulon, affect the carbohydrate fermentation phenotype in E. coli under certain physiological conditions, particularly under conditions of phosphate starvation. CysB, normally considered to be the central pleiotropic regulator of sulfur metabolism in enteric bacteria, has been shown to be required for normal acid induction of arginine decarboxylase (Shi \& Bennett, 1994) as well as for sensitivity to novobiocin (Rakonjac et al., 1991) and mecillinam (Oppezzo \& Antón, 1995). Thus, pleiotropic effects of $p h o B$ and $c y s B$ mutations other than those expected on the basis of their involvement in phosphorus and sulfur metabolic regulation, respectively, have been reported. In this report we present the results of our preliminary studies with representative examples of $c y s B$ mutant strains and provide analyses of the basis for specific carbohydrate utilization defects observed for these mutants.

\section{METHODS}

Strains and plasmids. The strains used in this study are listed in Table 1 . The cysB allele in MDA7K was transferred by P1 transduction to three different genetic backgrounds (bottom of Table 1), selecting for tetracycline resistance and screening for the $c y s B$ phenotype (non-growth on minimal medium and growth upon the addition of cysteine). Plasmids were introduced into the various E. coli strains by electroporation as described by O'Callaghan \& Charbit (1990).

Growth medium. The minimal medium contained $\mathrm{W}$ salts (100 $\mathrm{mM}$ potassium phosphate, $\mathrm{pH}$ 7, plus $1 \mathrm{mM} \mathrm{MgSO}_{4}$ )
(Smith et al., 1971) to which was added 0.01\% L-tryptophan when required (i.e. for strains LJ4508, LJ4510, LJ4511 and LJ4512) plus $0 \cdot 2 \%\left(\mathrm{NH}_{4}\right)_{2} \mathrm{SO}_{4}$ or another nitrogen source (when indicated) and the specified carbon source. For sulfurfree medium, $\mathrm{MgSO}_{4}$ was replaced by $\mathrm{MgCl}_{2}$ and $0.2 \%$ $\left(\mathrm{NH}_{4}\right)_{2} \mathrm{SO}_{4}$ was replaced by $0.4 \% \mathrm{NH}_{4} \mathrm{Cl}$. The rich medium used was Luria-Bertani (LB) broth or nutrient broth (NB). These media are limiting for cysteine, and growth of $c y s B$ mutants in these media requires addition of cysteine (an efficient sulfur source) or djenkolate (a limiting sulfur source).

Cell growth was always at $37^{\circ} \mathrm{C}$. Fermentation was tested on eosin-methylene blue (EMB) plates lacking lactose, but containing the indicated carbon source at $1 \%$, except for rhamnose which was present at $0.5 \%$. These plates, like the rich media described above, are sulfur-limited. Carbon oxidation was assayed using 96-well Biolog plates (Bochner, 1993). Cysteine, when present, was added to a final concentration of $0.2 \mathrm{mM}$. Although cysteine can be growthinhibiting at high concentrations (Harris \& Lui, 1981), it is not inhibitory at this concentration. For all enzyme assays, cells were harvested during exponential growth.

Enzyme assays. $\beta$-Galactosidase was assayed by the method described by Miller (1972). For the data presented in Table 5, which used minimal media, IPTG $(1 \mathrm{mM})$ was present during growth to eliminate any effect of the lac operon repressor. $\beta$-Galactosidase activities are either expressed in Miller

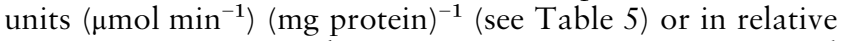
activities (see Figs 2 and 3). For reporter gene transcriptional fusion assays, cells were grown overnight in $5 \mathrm{ml} \mathrm{NB}$ plus $1 \%$ glucose, glucitol or formate at $37^{\circ} \mathrm{C}$ with agitation. Fresh NB $(100 \mathrm{ml})$ of the same composition was inoculated from the overnight culture and cells were harvested during exponential growth at $37^{\circ} \mathrm{C}\left(\mathrm{OD}_{600}\right.$ approx. $\left.0 \cdot 5\right)$. The cell density was adjusted and two drops of toluene were added to permeabilize the cells during vortexing for $30 \mathrm{~s}$. The samples were incubated at $30^{\circ} \mathrm{C}$ and aliquots were transferred to the appropriate buffers for reporter gene product assay. The $\beta$-galactosidase buffer consisted of $2 \mathrm{mM}$ EDTA, $70 \mathrm{mM} \mathrm{Na} \mathrm{HPO}_{4}, 35 \mathrm{mM}$ $\mathrm{NaH}_{2} \mathrm{PO}_{4}$ (pH 7·0), $1 \mathrm{mM} \mathrm{MgSO}{ }_{4}, 10 \mathrm{mM} \mathrm{KCl}$ and $10 \mathrm{mM} \beta$ mercaptoethanol. The same conditions were used to assay native $\beta$-galactosidase as reported in Table 5 . The $\beta$ glucuronidase buffer consisted of $50 \mathrm{mM}$ sodium phosphate, $\mathrm{pH} 7 \cdot 0,0 \cdot 1 \%$ Triton X-100 and $10 \mathrm{mM} \beta$-mercaptoethanol. The assay mixtures were allowed to equilibrate to room temperature for $10 \mathrm{~min}$ before addition of $200 \mu \mathrm{l} 0.4 \%$ onitrophenyl galactopyranoside (gut operon expression) or $100 \mu \mathrm{l} 10 \mathrm{mM} p$-nitrophenyl- $\beta$-D-glucuronide ( $f d o$ operon expression) to give a final volume of $1.0 \mathrm{ml}$. The nitrophenol released was measured after addition of $400 \mu \mathrm{l} 1 \mathrm{M} \mathrm{Na}_{2} \mathrm{CO}_{3}$ (gut operon expression) or $400 \mu \mathrm{l} 2.5 \mathrm{M}$ 2-amino-2-methylpropanediol ( $f d o$ operon expression) to stop the reaction. The samples were then read at 420 or $415 \mathrm{~nm}$, respectively (Jefferson et al., 1986; Miller, 1972). Protein concentrations were measured by the Lowry method.

Cell extracts for the assay of glucitol-6-phosphate dehydrogenase, Enzyme II $^{\text {Gut }}$ and D-alanine dehydrogenase activities were prepared as follows. Cells were grown with shaking in $\mathrm{LB}$ broth at $37^{\circ} \mathrm{C}$, harvested by centrifugation, washed three times with minimal medium 63 and resuspended in the same medium. PMSF $(0 \cdot 1 \mathrm{mM})$ and $\beta$-mercaptoethanol $\left(0.5 \mathrm{mg} \mathrm{ml}^{-1}\right)$ were added to the samples and the cells were lysed using a French press at 10000 p.s.i. (69 MPa). After centrifugation to remove cell debris, the supernatant was used for the assays. For the assay of glucitol-6-phosphate dehydrogenase activity, aliquots of the cell extracts were added to a solution containing $0.1 \mathrm{M}$ Tris $/ \mathrm{HCl}(\mathrm{pH} 8.5), 1.5 \mathrm{mM}$ 
Table 1. Bacterial strains and plasmids used in this study

\begin{tabular}{|c|c|c|}
\hline Strain/plasmid & Genotype/description & Reference or source \\
\hline \multicolumn{3}{|l|}{ S. typhimurium } \\
\hline LT2 & Wild-type & Ostrowski \& Kredich (1989) \\
\hline LT2 (cysB403) & cysB403 & Ostrowski \& Kredich (1989) \\
\hline \multicolumn{3}{|l|}{ E. coli } \\
\hline GNB7145K & MC4100 adi:: MudI1734(Kan ${ }^{\mathrm{R}}$ lac) relA1 & Shi \& Bennett (1994) \\
\hline MDA7K & MC4100 adi:: MudI1734 $\left(\operatorname{Kan}^{\mathrm{R}}\right.$ lac) cysB trpB:: $\operatorname{Tn} 10$ relA1 & Shi \& Bennett (1994) \\
\hline SB2249* & $c p d$ (Crooke's strain) & Castro et al. (1976) \\
\hline LJ2703* & $c p d p t s I^{\mathrm{ts}} \mathrm{crr}$ & Castro et al. (1976) \\
\hline LJ4508* & $c p d$ cysB $\operatorname{trp} B:: \operatorname{Tn} 10$ & This study \\
\hline LJ4510* & $c p d p t s I^{\text {ts }}$ crr cysB $\operatorname{trp} B:: \operatorname{Tn} 10$ & This study \\
\hline LJ4511* & $\operatorname{cpd} \operatorname{trp} B:: \operatorname{Tn} 10$ & This study \\
\hline LJ4512* & $c p d p t s I^{\mathrm{ts}} \operatorname{crr} \operatorname{trp} B:: \operatorname{Tn} 10$ & This study \\
\hline \multicolumn{3}{|l|}{ Plasmids } \\
\hline pCB182 & lacZ promoter probe vector $\left(\mathrm{Amp}^{\mathrm{R}}\right)$ & Schneider \& Beck (1986) \\
\hline pHA6 & $\mathrm{Amp}^{\mathrm{R}}$ fdo:: uidA $\left(\operatorname{Kan}^{\mathrm{R}}\right)$ & Abaibou et al. (1995) \\
\hline pGUTALAC1 & $\mathrm{Amp}^{\mathrm{R}}$ gutB: :lacZ† & This study \\
\hline
\end{tabular}

*All these strains are isogenic, being in the genetic background of Crooke's strain $(c p d)$.

† The gutB gene is also designated $s r l B$ (Berlyn, 1998).

$\mathrm{NAD}^{+}, 1 \mathrm{mM}$ dithiothreitol and $2 \mathrm{mM}$ glucitol 6-phosphate. The optical density at $340 \mathrm{~nm}$ was followed over a period of $2 \mathrm{~min}$. For the assay of Enzyme II ${ }^{\text {Gut }}, 0,1,2,5,10$ and $25 \mu \mathrm{l}$ samples of extract were added to $100 \mu \mathrm{l}$ twofold concentrated assay mix containing $100 \mathrm{mM}$ potassium phosphate buffer, $\mathrm{pH} 6 \cdot 0,20 \mu \mathrm{M}\left[{ }^{14} \mathrm{C}\right] \mathrm{D}$-glucitol, $20 \mathrm{mM}$ glucitol 6-phosphate, $50 \mathrm{mM} \mathrm{KF}, 25 \mathrm{mM} \mathrm{MgCl}_{2}$ and $5 \mathrm{mM}$ dithiothreitol. The samples were brought to $200 \mu \mathrm{l}$, final volume, vortexed and incubated at $37^{\circ} \mathrm{C}$ for $40 \mathrm{~min}$. One millilitre ice-cold water was then added to each assay tube to stop the reaction. The samples were applied to $\mathrm{NaCl}$ pre-washed ion-exchange columns (Saier et al., 1977), the columns were washed twice with $12 \mathrm{ml}$ water and the samples were eluted with $12 \mathrm{ml} 1 \mathrm{M}$ $\mathrm{LiCl}$ into scintillation vials containing Biosafe II scintillation cocktail in preparation for scintillation counting. For the D-alanine dehydrogenase assay, aliquots of cell extracts were added to a solution containing $2 \mathrm{mM}$ D-alanine, $10 \mathrm{mM}$ potassium phosphate, $\mathrm{pH} 7.5$, and $0.33 \mathrm{mg}$ dinitrophenyl hydrazine $\mathrm{ml}^{-1}$. At time intervals of $10 \mathrm{~min}$, the reaction was stopped by addition of $1.67 \mathrm{ml} 10 \% \mathrm{NaOH}$ and the absorbance was read at $445 \mathrm{~nm}$ as described by Wild et al. (1974; see also Saier et al., 1980).

Transport assays. Cells were grown with shaking at $37^{\circ} \mathrm{C}$ in LB medium, harvested during exponential growth by centrifugation, washed three times with minimal medium 63 and resuspended in the same medium. The cell suspensions were pre-warmed at $37^{\circ} \mathrm{C}$ for $10 \mathrm{~min}$ before ${ }^{14} \mathrm{C}$-labelled glucitol or D-alanine was added to a final concentration of $0 \cdot 1 \mathrm{mM}$. At intervals, samples were transferred to pre-washed $0.2 \mu \mathrm{m}$ (pore diameter) millipore filters. Cells were washed three times with medium 63 before the filters were dried, transferred to scintillation vials containing Biosafe-NA scintillation cocktail and counted.

CAMP assays. Cultures were grown for net cAMP production in minimal salts medium containing $1 \%$ lactate or $1 \%$ lactate plus $0.5 \%$ glucose for $5 \mathrm{~h}$ before samples were removed for extraction of cAMP (Castro et al., 1976). The optical density of the cultures $(600 \mathrm{~nm})$ was approximately $0 \cdot 6$. Samples were placed in a boiling water bath for $5 \mathrm{~min}$, chilled to $0^{\circ} \mathrm{C}$ and centrifuged to remove cell debris. Total cAMP was determined using partially purified cAMP-binding protein from beef muscle (Gilman, 1970), essentially as described previously (Castro et al., 1976; Feucht \& Saier, 1980). The amount of cAMP produced (Table 6) is expressed in nmol ( $\mathrm{mg}$ dry $\mathrm{wt})^{-1}$. No background activity was subtracted from the values presented.

\section{RESULTS}

\section{Effects of cysB mutations on carbon utilization in E. coli and S. typhimurium}

Table 2 records the Biolog results observed for cys $B$ mutants of both E. coli and S. typhimurium relative to their isogenic wild-type $\left(c y s B^{+}\right)$strains. The results observed for the $S$. typhimurium cysB mutant generally (but not always) paralleled those obtained with the $E$. coli mutant. Table 2 records the most pronounced effects observed. Clear-cut parallel effects were observed for D-alanine, L-fucose, D-glucitol, glucuronamide, $\alpha$ hydroxyglutaric acid $\gamma$-lactone and L-rhamnose. In two cases (D-glucuronate and D-gluconate), the S. typhimurium cysB mutant exhibited decreased utilization relative to its parental strain, but the E. coli mutant did not. In two cases (glycolate and glyoxylate), the E. coli $c y s B$ mutant exhibited decreased utilization relative to its wild-type strain, but the wild-type S. typhimurium strain did not exhibit a positive response towards either compound. In one case (formate), opposite responses were observed for S. typhimurium and E. coli cysB mutants (increased utilization in the former strain; decreased utilization for the latter strain). Although the catalytic repertoires for using carbon sources are similar in E. coli and Salmonella species, significant differences 
Table 2. Carbon oxidation by wild-type and $c y s B$ mutant strains of $S$. typhimurium and E. coli

Carbon oxidation was assayed using Biolog plates (Bochner, 1993). Relative responses were recorded as follows: +++ , very strong; ++ , strong; + , weak; - , no response.

\begin{tabular}{|c|c|c|c|c|}
\hline \multirow[t]{2}{*}{ Substrate } & \multicolumn{2}{|c|}{ S. typhimurium } & \multicolumn{2}{|c|}{ E. coli } \\
\hline & WT & cysB & WT & $c y s B$ \\
\hline D-Alanine & ++ & + & +++ & ++ \\
\hline Cellobiose & - & - & + & - \\
\hline Formate & + & +++ & +++ & ++ \\
\hline L-Fucose & +++ & - & +++ & - \\
\hline D-Glucitol & ++ & - & ++ & - \\
\hline Glucuronamide & + & - & ++ & - \\
\hline D-Glucuronate & ++ & + & +++ & +++ \\
\hline D-Gluconate & ++ & + & +++ & +++ \\
\hline Glycolate & - & - & ++ & - \\
\hline Glyoxylate & - & - & ++ & - \\
\hline $\begin{array}{l}\alpha \text {-Hydroxyglutaric } \\
\text { acid } \gamma \text {-lactone }\end{array}$ & + & - & ++ & - \\
\hline L-Rhamnose & +++ & + & +++ & - \\
\hline
\end{tabular}

Table 3. Fermentation properties of $c y s B$ mutants of S. typhimurium and $E$. coli on solid medium

Sugars were present at $1 \%$, with the exception of rhamnose $(0.5 \%)$. Djenkolate and cysteine when present were included in the fermentation medium at $1 \mathrm{mg} \mathrm{ml}^{-1}$. ++ , Strong fermentation; - , no fermentation; + or \pm , intermediate fermentation responses. Relative colour on EMB plates was evaluated for individual colonies. Triplicate determinations gave comparable results.

\begin{tabular}{|c|c|c|c|c|}
\hline \multirow[t]{2}{*}{ Fermentation (EMB) } & \multicolumn{2}{|c|}{ S. typhimurium } & \multicolumn{2}{|c|}{ E. coli } \\
\hline & WT & $c y s B$ & WT & $c y s B$ \\
\hline L-Fucose & ++ & \pm & ++ & \pm \\
\hline Glucose & ++ & + & ++ & + \\
\hline Galactose & ++ & + & ++ & + \\
\hline Mannitol & ++ & + & ++ & + \\
\hline L-Rhamnose & ++ & \pm & ++ & - \\
\hline Glucitol & ++ & \pm & ++ & \pm \\
\hline Glucitol + djenkolate & ++ & + & ++ & + \\
\hline Glucitol + cysteine & ++ & + & ++ & + \\
\hline
\end{tabular}

are found even among the strains and substrains of each species (Lin, 1996).

\section{Fermentation properties of $c y s B$ mutants of S. typhimurium and E. coli}

Table 3 summarizes the results of carbohydrate fermentation responses of wild-type and cysB mutant

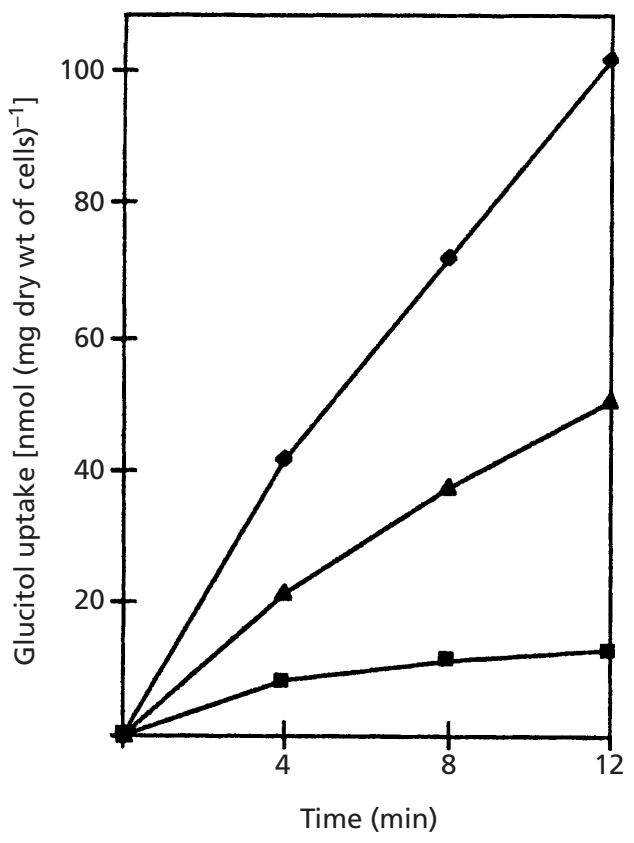

Fig. 1. Uptake of $\left[{ }^{14} \mathrm{C}\right]$ glucitol by wild-type cells $(\diamond)$ and by cys $B$ mutant cells grown in LB broth plus $0.5 \%$ glucitol with ( $(\mathbf{A})$ or without $(\boldsymbol{\square})$ djenkolate at a concentration of $1 \mathrm{mg} \mathrm{ml}^{-1}$. Cells were harvested $3 \mathrm{~h}$ after inoculation during exponential growth as described under Methods.

strains to select compounds. The cysB mutants of $S$. typhimurium and E. coli generally did not ferment carbohydrates as well as did the isogenic parents, and for both bacterial species, responses towards L-rhamnose and D-glucitol appeared to be most pronounced. On minimal medium, both $c y s B$ mutants exhibited negligible growth regardless of the carbon source present, as expected, since the $c y s B$ mutation gives rise to a requirement for exogenous cysteine or another sulfur source (data not shown). In all cases examined, inclusion of cysteine or djenkolate in the media partially, but not completely, reversed the growth phenotype. Even high concentrations of these compounds did not restore wild-type growth responses (data not shown).

\section{Glucitol uptake in S. typhimurium}

Fig. 1 shows time courses for the uptake of $\left[{ }^{14} \mathrm{C}\right] \mathrm{D}$ glucitol by $S$. typhimurium strain LT-2 and by the isogenic cys $B$ mutant following growth in LB broth (moderately sulfur-limiting conditions comparable to our fermentation conditions). Uptake was reduced nearly tenfold by loss of CysB. When the $c y s B$ mutant was grown in the presence of glucitol plus djenkolate, uptake was partially restored. These results are in full agreement with the fermentation results recorded in Table 3. 
Table 4. Effects of a cysB mutation on the specific activities of transport systems and enzymes concerned with glucitol and alanine utilization in S. typhimurium

Cells were grown in LB broth (moderately sulfur-limiting conditions $\pm 1 \mathrm{mg} \mathrm{L-djenkolate} \mathrm{ml}^{-1}$ ), harvested in the exponential growth phase and prepared for transport or enzyme assay as described in Methods. One hundred percent corresponds to the following values: glucitol transport, $5 \mathrm{nmol}$ $(\mathrm{mg} \text { dry wt) })^{-1} \mathrm{~min}^{-1}$; Enzyme II ${ }^{\text {Gut }}$ (measured in vitro), $750 \mathrm{nmol}(\mathrm{mg} \text { protein })^{-1} \mathrm{~min}^{-1}$; glucitol-6phosphate dehydrogenase, $630 \mathrm{nmol}(\mathrm{mg} \text { protein })^{-1} \mathrm{~min}^{-1}$; D-alanine transport, $1.2 \mathrm{nmol}(\mathrm{mg}$ dry $\mathrm{wt})^{-1} \mathrm{~min}^{-1}$; D-alanine dehydrogenase, $70 \mathrm{nmol}(\mathrm{mg} \text { protein })^{-1} \mathrm{~min}^{-1}$. ND, Not determined.

\begin{tabular}{|lccc|}
\hline Activity measured & \multicolumn{3}{c|}{ Relative activity (\%) } \\
\cline { 2 - 4 } & WT & $c \boldsymbol{s} \boldsymbol{B}$ & $\boldsymbol{c} \boldsymbol{s} \boldsymbol{s}$ B + djenkolate \\
\hline Glucitol transport & $100 \pm 2$ & $13 \pm 3$ & $48 \pm 5$ \\
Enzyme II ${ }^{\text {uut }}$ & $100 \pm 22$ & $52 \pm 24$ & $73 \pm 18$ \\
Glucitol-6-phosphate dehydrogenase & $100 \pm 38$ & $54 \pm 23$ & $63 \pm 23$ \\
D-Alanine transport & $100 \pm 15$ & $71 \pm 11$ & ND \\
D-Alanine dehydrogenase & $100 \pm 30$ & $9 \pm 6$ & ND \\
\hline
\end{tabular}

\section{Effects of cysB mutations on the specific activities of enzymes and transport systems concerned with glucitol and D-alanine utilization}

Table 4 summarizes the results of studies aimed at quantifying the specific activities of transport systems and catabolic enzymes concerned with glucitol and Dalanine utilization in S. typhimurium. Glucitol is utilized via a pathway that involves concomitant transport and phosphorylation of the sugar, yielding cytoplasmic glucitol 6-phosphate, followed by oxidation of glucitol 6-phosphate to fructose 6-phosphate (Lengeler, 1975a, b). The Enzyme II Gut (glucitol PTS permease) and glucitol-6-phosphate dehydrogenase were therefore assayed in crude extracts derived from wild-type and $c y s B$ mutant cells of $S$. typhimurium. As summarized in Table 4 , both activities were depressed to about $50 \%$ of the wild-type level by the $c y s B$ mutation, and the inclusion of djenkolate in the growth medium partially restored these activities. Inclusion of cysteine had an effect similar to that of djenkolate (data not shown). These results are in agreement with the fermentation and transport results cited above.

When D-alanine uptake and D-alanine dehydrogenase were similarly assayed, qualitatively similar results were obtained. Thus, D-alanine transport activity was reduced to $70 \%$ whilst $\mathrm{D}$-alanine dehydrogenase activity decreased to $9 \%$. The dramatic effect of the cysB mutation on D-alanine dehydrogenase activity can account for the poor response to alanine as measured with Biolog plates.

\section{Use of reporter gene transcriptional fusions to study the effects of a cys $B$ mutation on gene expression}

A plasmid bearing a gutB-lacZ transcriptional fusion was transformed into wild-type and $c y s B$ mutant strains of E. coli. Cells bearing this multicopy plasmid were then grown in nutrient medium under non-inducing, repressing and inducing conditions as described in Methods. The lack of induction by glucitol presumably reflects the multiple copies of the gut operon control region since the chromosomally encoded regulatory proteins, GutM and GutR (Yamada \& Saier, 1988), may not be present in sufficient amounts to regulate all plasmid operators. The results depicted in Fig. 2(a) clearly show that when cells were grown under either non-inducing conditions (NB alone) or inducing conditions (NB plus $1 \%$ glucitol), the presence of the $c y s B$ mutation drastically reduced glucitol operon expression (Yamada \& Saier, 1987, 1988; Yamada et al., 1990). CRP is present in E. coli cells in large amounts. Consequently, catabolite repression would not be expected to be altered by expression of a target gene on a multicopy plasmid. As can be seen, strong catabolite repression is observed. Unexpectedly, however, there was little effect of the $c y s B$ mutation under glucoserepressing conditions.

Comparable experiments were conducted with a transcriptional reporter gene fusion to the fdoGHI (aerobic formate dehydrogenase) operon. In this $f d o G$-uidA fusion, the reporter gene encodes $\beta$-glucuronidase (Abaibou et al., 1995) (Fig. 2b). Results paralleled those observed for the glucitol operon gene fusion. Thus, induced and uninduced activities were comparable, and unrepressed activity (i.e. in NB-grown cells) was reduced about twofold by the $c y s B$ mutation. This activity was largely restored by inclusion of cysteine in the growth medium. By contrast, glucose-repressed activity was only weakly affected by the $c y s B$ mutation. These results led to the possibility that the $c y s B$ mutation prevented the normal cAMP-CRP-mediated activation of catabolite-sensitive operons under non-repressing conditions. Activity under non-repressing conditions 


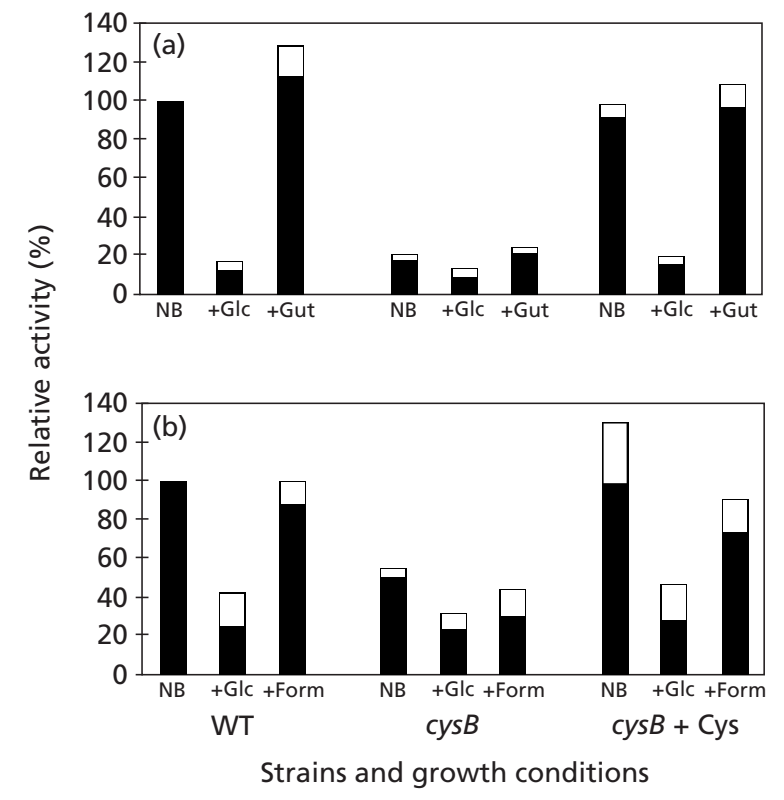

Fig. 2. Transcription of the glucitol (gut, a) and formate dehydrogenase $(f d o, b)$ operons in wild-type (WT) and cys $B$ mutant strains of $E$. coli. (a) A plasmid-encoded gutB-lac $Z$ fusion was introduced into the two strains by electroporation as described in Methods. Cells were grown in NB with or without glucose (Glc; $1 \%$ ) or glucitol (Gut; $1 \%$ ) at $37{ }^{\circ} \mathrm{C}$ for $3 \mathrm{~h}$ before harvesting, cell rupture and assay of $\beta$-galactosidase. (b) $\mathrm{A}$ plasmid-encoded fdoG-uidA fusion was similarly introduced into the two strains by electroporation. The transformed cells were grown in nutrient broth with or without formate (Form) or glucose (GIc) (1\% each) for $3 \mathrm{~h}$ before harvesting, cell rupture and assay of $\beta$-glucuronidase as described in Methods. White boxes at the top of the dark bars denote the error expressed in standard deviations with the measured mean values denoted by the dark bars. The lack of induction reflects the use of high-copy-number plasmids.

was thus affected by the $c y s B$ mutation much more than that under repressing conditions.

\section{Effect of exogenous CAMP on gene expression}

The results reported in Fig. 2 suggested that the $c y s B$ defect might interfere with the function of the cAMPCRP complex that normally activates catabolite-sensitive genes. To test this possibility, expression of the two reporter gene fusions (gutB-lacZ and $f d o G-u i d A$ ) was studied as a function of the concentration of exogenous cAMP. The results are summarized in Fig. 3. As can be seen, cAMP increased expression of both fusions in the $c y s B$ genetic background, but decreased expression of both fusions in the wild-type background. The mild repressive effect in the wild-type background suggests that, in the absence of exogenous cAMP, these cells synthesize sufficient cAMP for maximal transcription. The results suggest that a primary deficiency, giving rise to defective expression of carbon catabolic enzyme-encoding genes, is related to depressed levels of cytoplasmic cAMP in the $c y s B$ mutant relative to the wild-type strain.

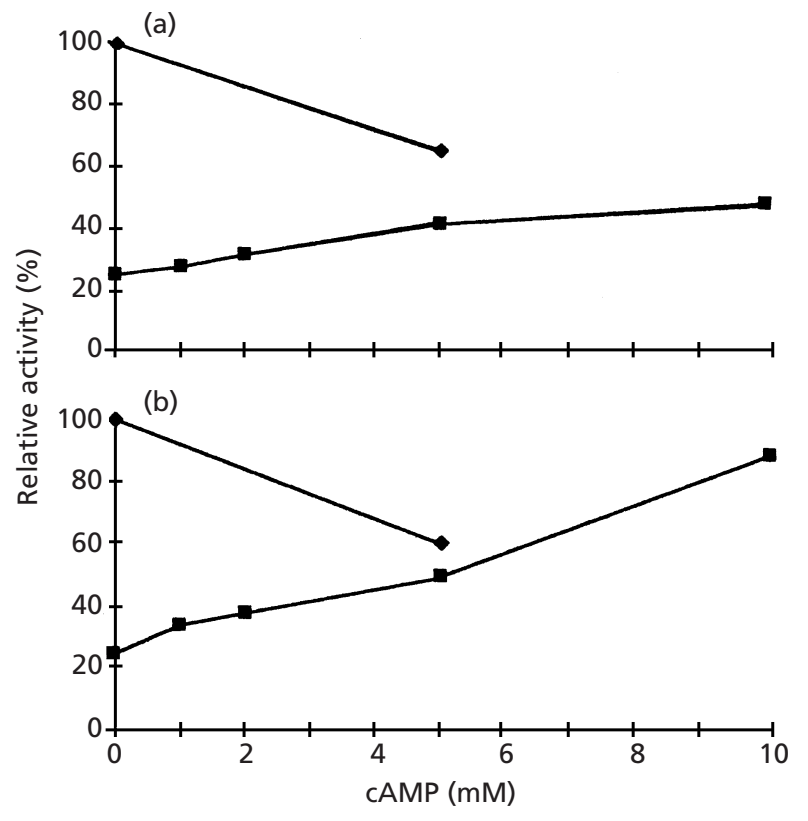

Fig. 3. Effects of CAMP on expression of the genes encoding Enzyme IIA of the glucitol PTS (a) and formate dehydrogenase (b) of E. coli. Cells (WT, $\bullet$; cysB, $\square$ ) were grown at $37^{\circ} \mathrm{C}$ in nutrient broth for $3 \mathrm{~h}$ in the presence of the concentration of exogenous CAMP indicated. $\beta$-Galactosidase (a) or $\beta$ glucuronidase (b) was assayed as described in Methods. Five millimolar CAMP depressed growth rates of the wild-type strain, but not of the cysB mutant.

Table 5. $\beta$-Galactosidase levels in Crooke's strain and the isogenic cys $B$ mutant strain

Growth conditions were as described in Methods using the minimal sulfate-free medium with $1 \%$ DL-lactate, $0.5 \%$ D-glucose, $0.01 \%$ L-tryptophan, $0.2 \mathrm{mM}$ cysteine or $1 \mathrm{mM}$ djenkolate as indicated above. IPTG $(1 \mathrm{mM})$ was present under all conditions to neutralize the effect of the lac operon repressor.

\begin{tabular}{|lcc|}
\hline \multirow{2}{*}{ Medium } & $\boldsymbol{\beta}$-Galactosidase activity (Miller units) \\
\cline { 2 - 3 } & Wild-type & $\boldsymbol{c} \boldsymbol{s} \boldsymbol{B}$ \\
\hline Lactate djenkolate & $3030 \pm 240$ & $2500 \pm 290$ \\
Lactate cysteine & $3610 \pm 290$ & $3200 \pm 220$ \\
Glucose djenkolate & $1900 \pm 100$ & $450 \pm 110$ \\
Glucose cysteine & $1700 \pm 110$ & $1600 \pm 120$ \\
\hline
\end{tabular}

\section{Control of lac operon expression in response to sulfur limitation}

Table 5 presents the results of experiments designed to test the effects of sulfur limitation on native $\beta$ galactosidase synthesis when lac $Z$ is expressed under the control of the lac operon promoter and control region. These experiments were conducted in the genetic background of Crooke's strain (SB2249; cpd; Castro et al., 1976). Since this strain lacks cAMP phospho- 
Table 6. cAMP levels in strains grown on lactate and djenkolate

The concentrations were as follows: DL-lactate, $1 \%$; L-djenkolate, $1 \mathrm{mM}$; L-tryptophan, $0 \cdot 01 \%$ (present in all cultures); D-glucose, $0.5 \%$ (present + glucose only).

\begin{tabular}{|llrr|}
\hline Strain & \multirow{2}{*}{ Relevant genotype } & cAMP [nmol (mg dry wt $)^{-1}$ ] \\
\cline { 3 - 4 } & & & + Glucose \\
\hline LJ4511 & $c p d$ & $1 \cdot 10 \pm 0 \cdot 11$ & $0 \cdot 39 \pm 0 \cdot 04$ \\
LJ4508 & $c p d c y s B$ & $1 \cdot 02 \pm 0 \cdot 14$ & $0 \cdot 29 \pm 0 \cdot 03$ \\
LJ4512 & $c p d p t s I^{\text {ss }} c r r$ & $0 \cdot 45 \pm 0 \cdot 08$ & $0 \cdot 61 \pm 0 \cdot 12$ \\
LJ4510 & $c p d p t s I^{\text {s }} c r r c y s B$ & $0 \cdot 34 \pm 0 \cdot 04$ & $0 \cdot 56 \pm 0 \cdot 07$ \\
\hline
\end{tabular}

diesterase, cAMP degradation cannot occur. This leads to higher cytoplasmic levels of this nucleotide. In the wild-type strain, $\beta$-galactosidase activity was high when cells were grown in $1 \%$ lactate-containing minimal medium and substantially lower when grown in the presence of $0.5 \%$ glucose. Under these conditions, the presence of djenkolate or cysteine had little effect on lac $Z$ expression, although expression was slightly higher when cysteine $(0.2 \mathrm{mM})$ was present as compared with djenkolate $(1 \mathrm{mM})$. These results are consistent with the conclusion that in $c y s B^{+}$cells, cAMP is present at high cytoplasmic concentrations and glucose only moderately reduces these concentrations. However, in the isogenic cys $B$ mutant, lactate-grown cells showed substantially less $\beta$-galactosidase activity than the wild-type strain and the difference between cysteine- and djenkolategrown cells was somewhat greater. Growth in the presence of djenkolate is known to promote sulfur limitation in a $c y s B$ mutant to a greater extent than growth in the presence of cysteine (Kredich, 1996). Most striking, however, was the effect of sulfur limitation on the $c y s B$ mutant when grown in the presence of glucose plus djenkolate. $\beta$-Galactosidase activity dropped to about $20 \%$ of the value obtained when the wild-type strain was grown with glucose with or without either cysteine or djenkolate. Activity was also high when the $c y s B$ mutant was grown with glucose plus cysteine. These results show that lac $Z$ expression is greatly reduced only in the $c y s B$ mutant under conditions of sulfur starvation and substantiate the suggestion that sulfur limitation lowers cellular cAMP levels.

\section{Direct measurement of CAMP production}

Total cAMP production (cells plus medium) was quantified in the same isogenic $c p d$ and $c p d c y s B$ strains used in the experiments described in the previous section (Table 6). In this experiment, cells were grown in the same minimal medium supplemented with lactate or glucose plus djenkolate. Because Crooke's strain (SB2249) lacks the cAMP-degradative enzyme, cAMP phosphodiesterase, it is clear that the effects are due to the regulation of cAMP synthesis, not cAMP degradation.
The cys $B$ mutant showed slightly lower cAMP production than the isogenic $c y s B^{+}$strain when lactate was the sole carbon source present. In the presence of glucose, however, cAMP production was greatly reduced and the $c y s B$ mutation reduced production even further. The presence of the $p t s I \mathrm{crr}$ double mutations reduced cAMP production during growth on lactate, but increased production in the presence of glucose. In this case, glucose may have increased cAMP production by increasing energy availability and thereby increasing the level of ATP in the cell. $\mathrm{cr}$ mutants are insensitive to PTS-mediated regulation of adenylate cyclase (Castro et al., 1976; Feucht \& Saier, 1980). In the crr genetic background, in the presence of glucose, the cys $B$ mutation did not reduce cAMP production levels to those observed for glucose-grown LJ4508 (cysB). The results are therefore in qualitative agreement with the results presented in Table 5, assuming that cellular cAMP levels explain the results reported therein. The data suggest, but are insufficient to establish, that CysB exerts its effect on adenylate cyclase by influencing the PTS-regulatory apparatus rather than directly affecting adenylate cyclase itself.

\section{DISCUSSION}

Mutations affecting pleiotropic transcription factors controlling nitrogen, sulfur, phosphorus or iron also have a negative effect on carbon utilization (Hantke, 1987; Hartmann \& Boos, 1993; Shi \& Bennett, 1994; and our unpublished results). Thus, for example, in E. coli, using Biolog plates, a phoB mutant showed decreased glucose, maltose, melibiose and trehalose utilization, a $g \ln B$ mutant exhibited overall weaker responses than did the parental strain and a fur mutant showed poor utilization of proline, L-fucose, D, L- $\alpha$-glycerol phosphate, formate, L-rhamnose, fumarate and glycyl-Laspartate. In some cases, these effects might be indirect, due to a deficiency for one or more specific compound(s) synthesized or secured by the cell. Such a compound might be required for carbon metabolic processes to proceed normally. Such indirect effects may be of great physiological significance, allowing the bacterium to coordinate the utilization of one nutrient class of compounds with another. We anticipate that such regulatory effects have been selected for during evolution. However, very few studies have addressed the mechanisms by which these regulatory interactions occur.

Recently, evidence for a connection between the cAMPCRP-regulated modulon and the stringent response in $E$. coli has been reported (Johansson et al., 2000). Moreover, the homologous nucleoid proteins, H-NS and StpA, were shown to play a positive role in expression of stringently regulated genes as well as in cell growth. The results reported suggest that catabolite repression, the stringent response and control of gene expression by structural nucleoid proteins are all interconnected (Johansson et al., 2000). The relationship between these observations and those reported here, if any, have yet to 
be investigated, but the results of Johansson et al. (2000) corroborate our postulate that the different regulons in the bacterial cell are interrelated.

In this communication, we not only document the effects of $c y s B$ mutations in E. coli and S. typhimurium on carbon oxidation and carbohydrate fermentation, but we also pursue the effect of the $c y s B$ mutation on carbon utilization to the mechanistic level. The results reported revealed that the effects were at the transcriptional level for both the gut and the $f d o$ operons. Both effects appear to be partially reversed by exogenous cAMP or a sulfur source such as cysteine or djenkolate. Furthermore, we provide evidence that the effect is on regulation of the cAMP biosynthetic enzyme, adenylate cyclase, by the IIA $^{\text {Glc }}$ protein of the PTS, and not on the inherent activity of adenylate cyclase itself. Our current postulate is that these effects are indirect, that they affect the regulation of adenylate cyclase as a primary target and that the level and/or activity of this enzyme will prove to be hypersensitive to the metabolic state of the cell. Such sensitivity would allow the bacterium to coordinate carbon/energy metabolism with the availability of other macro- and micronutrients. The mechanistic details of these interactions are currently under study in our laboratory.

\section{ACKNOWLEDGEMENTS}

We thank Jackie Richardson and Mary Beth Hiller for assistance in the preparation of this manuscript. This work was supported by USPHS grant AI14176 from the National Institute of Allergy and Infectious Diseases.

\section{REFERENCES}

Abaibou, H., Pommier, J., Benoit, S., Giordano, G. \& MandrandBerthelot, M. A. (1995). Expression and characterization of the Escherichia coli fdo locus and a possible physiological role for aerobic formate dehydrogenase. J Bacteriol 177, 7141-7149.

Antón, D. N. (2000). Induction of the cysteine regulon of Salmonella typhimurium in LB medium affects the response of cysB mutants to mecillinam. Curr Microbiol 40, 72-77.

Berlyn, M. K. (1998). Linkage map of Escherichia coli K12, edition 10: the traditional map. Microbiol Mol Biol Rev 62, 814-984.

Bochner, B. (1993). Advances in the identification of bacteria and yeast. Am Clin Lab 12, 6.

Castro, L., Feucht, B. U., Morse, M. L. \& Saier, M. H., Jr (1976). Regulation of carbohydrate permeases and adenylate cyclase in Escherichia coli. Studies with mutant strains in which enzyme I of the phosphoenolpyruvate:sugar phosphotransferase system is thermolabile. J Biol Chem 251, 5522-5527.

Dassler, T., Maier, T., Winterhalter, C. \& Bock, A. (2000). Identification of a major facilitator protein from Escherichia coli involved in efflux of metabolites of the cysteine pathway. Mol Microbiol 36, 1101-1112.

Earhart, C. F. (1996). Uptake and metabolism of iron and molybdenum. In Escherichia coli and Salmonella: Cellular and Molecular Biology, 2nd edn, pp. 1075-1090. Edited by F. C. Neidhardt and others. Washington, DC: American Society for Microbiology.
Feucht, B. U. \& Saier, M. H., Jr (1980). Fine control of adenylate cyclase by the phosphoenol-pyruvate:sugar phosphotransferase systems in Escherichia coli and Salmonella typhimurium. J Bacteriol 141, 603-610.

Gilman, A. G. (1970). A protein binding assay for adenosine $3^{\prime}: 5^{\prime}$ cyclic monophosphate. Proc Natl Acad Sci U S A 67, 305-312.

Gralla, J. D. \& Collado-Vides, J. (1996). Organization and function of transcription regulatory elements. In Escherichia coli and Salmonella: Cellular and Molecular Biology, 2nd edn, pp. 1232-1245. Edited by F. C. Neidhardt and others. Washington, DC: American Society for Microbiology.

Hantke, K. (1987). Selection procedure for deregulated iron transport mutants (fur) in Escherichia coli K12: fur not only affects iron metabolism. Mol Gen Genet 210, 135-139.

Harris, C. L. \& Lui, L. (1981). Cysteine and growth inhibition of Escherichia coli: derepression of the ilvGEDA operon. Biochem Biophys Res Commun 101, 1145-1151.

Hartmann, A. \& Boos, W. (1993). Mutations in $p h o B$, the positive gene activator of the pho regulon in Escherichia coli, affect the carbohydrate phenotype on MacConkey indicator plates. Res Microbiol 144, 285-293.

Hryniewicz, M. M. \& Kredich, N. M. (1991). The cysP promoter of Salmonella typhimurium: characterization of two binding sites for CysB protein, studies of in vivo transcription initiation, and demonstration of the anti-inducer effects of thiosulfate. $J$ Bacteriol 173, 5876-5886.

Jefferson, R. A., Burgess, S. M. \& Hirsh, D. (1986). $\beta$-Glucuronidase from E. coli as a gene-fusion marker. Proc Natl Acad Sci U S A 83, 8447-8451.

Johansson, J., Balsalobre, C., Wang, S.-Y., Urbonaviciene, J., Jin, D. J., Sondén, B. \& Uhlin, B. E. (2000). Nucleoid proteins stimulate stringently controlled bacterial promoters: a link between the cAMP-CRP and the (p)ppGpp regulons in Escherichia coli. Cell 102, 475-485.

Kredich, N. M. (1992). The molecular basis for positive regulation of cys promoters in Salmonella typhimurium and Escherichia coli. Mol Microbiol 6, 2747-2753.

Kredich, N. M. (1996). Biosynthesis of cysteine. In Escherichia coli and Salmonella: Cellular and Molecular Biology, 2nd edn, pp. 514-527. Edited by F. C. Neidhardt and others. Washington, DC: American Society for Microbiology.

Lengeler, J. (1975a). Mutations affecting transport of the hexitols D-mannitol, D-glucitol, and galactitol in Escherichia coli K-12: isolation and mapping. J Bacteriol 124, 26-38.

Lengeler, J. (1975b). Nature and properties of hexitol transport systems in Escherichia coli. J Bacteriol 124, 39-47.

Lin, E. C. C. (1996). Dissimilatory pathways for sugars, polyols, and carboxylates. In Escherichia coli and Salmonella: Cellular and Molecular Biology, 2nd edn, pp. 307-342. Edited by F. C. Neidhardt and others. Washington, DC: American Society for Microbiology.

Lochowska, A., Iwanicka-Nowicka, R., Plochocka, D. \& Hryniewicz, M. M. (2001). Functional dissection of the LysR-type CysB transcriptional regulator. Regions important for DNA binding, inducer response, oligomerization, and positive control. J Biol Chem 276, 2098-2107.

Magasanik, B. (1996). Regulation of nitrogen utilization. In Escherichia coli and Salmonella: Cellular and Molecular Biology, 2nd edn, pp. 1344-1356. Edited by F. C. Neidhardt and others. Washington, DC: American Society for Microbiology. 
Miller, J. H. (1972). Experiments in Molecular Genetics, pp. 352-355. Cold Spring Harbor, NY: Cold Spring Harbor Laboratory.

O'Callaghan, D. \& Charbit, A. (1990). High efficiency transformation of Salmonella typhimurium and Salmonella typhi by electroporation. Mol Gen Genet 223, 156-158.

Oppezzo, O. J. \& Antón, D. N. (1995). Involvement of $c y s B$ and $c y s E$ genes in the sensitivity of Salmonella typhimurium to mecillinam. J Bacteriol 177, 4524-4527.

Ostrowski, J. \& Kredich, N. M. (1989). Molecular characterization of the cysJIH promoters of Salmonella typhimurium and Escherichia coli: regulation by $c y s B$ protein and $\mathrm{N}$-acetyl-Lserine. J Bacteriol 171, 130-140.

Ostrowski, J. \& Kredich, N. M. (1990). In vitro interactions of CysB protein with the cysJIH promoter of Salmonella typhimurium: inhibitory effects of sulfide. J Bacteriol 172, 779-785.

van der Ploeg, J. R., Iwanicka-Nowicka, R., Kertesz, M. A., Leisinger, T. \& Hryniewicz, M. M. (1997). Involvement of CysB and $\mathrm{Cbl}$ regulatory proteins in expression of the $\tan A B C D$ operon and other sulfate starvation-inducible genes in Escherichia coli. J Bacteriol 179, 7671-7678.

Rakonjac, J., Milic, M. \& Savic, D. J. (1991). $c y s B$ and $c y s E$ mutants of Escherichia coli $\mathrm{K} 12$ show increased resistance to novobiocin. Mol Gen Genet 228, 307-311.

Reitzer, L. J. (1996a). Ammonia assimilation and the biosynthesis of glutamine, glutamate, aspartate, asparagine, L-alanine and Dalanine. In Escherichia coli and Salmonella: Cellular and Molecular Biology, 2nd edn, pp. 391-407. Edited by F. C. Neidhardt and others. Washington, DC: American Society for Microbiology.

Reitzer, L. J. (1996b). Sources of nitrogen and their utilization. In Escherichia coli and Salmonella: Cellular and Molecular Biology, 2nd edn, pp. 380-390. Edited by F. C. Neidhardt and others. Washington, DC: American Society for Microbiology.

Saier, M. H., Jr \& Ramseier, T. M. (1996). The catabolite repressor/activator (Cra) protein of enteric bacteria. J Bacteriol 178, 3411-3417.

Saier, M. H., Jr, Feucht, B. U. \& Mora, W. K. (1977). Sugar phosphate:sugar transphosphorylation and exchange group translocation catalyzed by the Enzyme II complexes of the bacterial phosphoenolpyruvate:sugar phosphotransferase system. J Biol Chem 252, 8899-8907.
Saier, M. H., Jr, Ramseier, T. M. \& Reizer, J. (1996). Regulation of carbon utilization. In Escherichia coli and Salmonella: Cellular and Molecular Biology, 2nd edn, pp. 1325-1343. Edited by F. C. Neidhardt and others. Washington, DC: American Society for Microbiology.

Saier, M. H., Schmidt, M. R. \& Lin, P. (1980). Phosphoryl exchange reaction catalyzed by Enzyme I of the bacterial phosphoenolpyruvate:sugar phosphotransferase system. Kinetic characterization. J Biol Chem 255, 8579-8584.

Schneider, K. \& Beck, C. F. (1986). Promoter-probe vectors for the analysis of divergently arranged promoters. Gene 42, 37-48.

Seiflein, T. A. \& Lawrence, J. G. (2001). Methionine-to-cysteine recycling in Klebsiella aerogenes. J Bacteriol 183, 336-346.

Shi, X. \& Bennett, G. N. (1994). Effects of $r p o A$ and $c y s B$ mutations on acid induction of biodegradative arginine decarboxylase in Escherichia coli. J Bacteriol 176, 7017-7023.

Smith, G. R., Halpern, Y. S. \& Magasanik, B. (1971). Genetic and metabolic control of enzymes responsible for histidine degradation in Salmonella typhimurium. 4-Imidazolone-5-propionate amidohydrolase and $\mathrm{N}$-formimino-L-glutamate formiminohydrolase. J Biol Chem 246, 3320-3329.

Wanner, B. L. (1996). Phosphorus assimilation and control of the phosphate regulon. In Escherichia coli and Salmonella: Cellular and Molecular Biology, 2nd edn, pp. 1357-1381. Edited by F. C. Neidhardt and others. Washington, DC: American Society for Microbiology.

Wild, J., Walczak, W., Krajewska-Grynkiewicz, K. \& Klopotowski, T. (1974). D-amino acid dehydrogenase: the enzyme of the first step of D-histidine and D-methionine racemization in Salmonella typhimurium. Mol Gen Genet 128, 131-146.

Yamada, M. \& Saier, M. H., Jr (1987). Glucitol-specific enzymes of the phosphotransferase system in Escherichia coli. Nucleotide sequence of the gut operon. J Biol Chem 262, 5455-5463.

Yamada, M. \& Saier, M. H., Jr (1988). Positive and negative regulators for glucitol (gut) operon expression in Escherichia coli. J Mol Biol 203, 569-583.

Yamada, M., Yamada, Y. \& Saier, M. H., Jr (1990). Nucleotide sequence and expression of the gutQ gene within the glucitol operon of Escherichia coli. DNA Seq 1, 141-145.

Received 5 March 2001; revised 12 July 2001; accepted 23 August 2001. 